\title{
Protective Effects of Petroselinum crispum (Parsley) Extract Against Methotrexate-Induced Hepatotoxicity
}

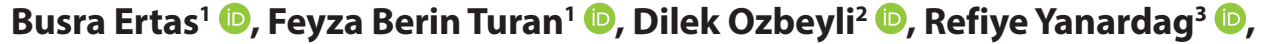 \\ Ozlem Sacan ${ }^{3}$ (D), Goksel Sener ${ }^{4}$ (D)
}

'Marmara University, School of Pharmacy, Department of Pharmacology, Istanbul, Turkey

${ }^{2}$ Marmara University, Vocational School of Health Services, Medical Pathology Techniques, Istanbul, Turkey

${ }^{3}$ Istanbul University, Faculty of Engineering, Department of Biochemistry, Istanbul, Turkey

${ }^{4}$ Fenerbahce University, Vocational School of Health Services, Istanbul, Turkey

ORCID IDs of the authors: B.E. 0000-0001-8374-1098; F.B.T. 0000-0002-0436-7876; D. O. 0000-0002-0250-9535;

R.Y. 0000-0003-4185-4363; O.S. 0000-0001-6503-4613; G.S. 0000-0001-7444-6193

Please cite this article as: Ertas B, Turan FB, Ozbeyli D, Yanardag R, Sacan O, Sener G. Protective Effects of Petroselinum crispum (Parsley) Extract Against Methotrexate-Induced Hepatotoxicity. Eur J Biol 2021; 80(2): 173-178. DOI: 10.26650/EurJBiol.2021.1023136

\section{ABSTRACT}

Objective: By inhibiting the synthesis of thymidine and purine, and thereby DNA synthesis, Methotrexate (MTX), suppresses the proliferation of cancer cells. It is thought that the side-effect mechanism is related to oxidant molecules derived from MTX metabolism. In this study, we examined whether the Petroselinum crispum extracts (PCr; parsley) of which the antioxidant properties have been previously shown, was protective against MTX induced liver damage.

Materials and Methods: Sprague Dawley rats (female/male; 200-250 g) were used. MTX was injected intraperitoneally and $\mathrm{PCr}$ extract was given orally. A single dose of $20 \mathrm{mg} / \mathrm{kg}$ MTX was administered to the groups that were to experience hepatotoxicity. Then, a physiological saline (MTX group) or PCr ( $2 \mathrm{~g} / \mathrm{kg}, \mathrm{MTX}+\mathrm{PCr}$ group) treatment was applied for 5 days. The same treatments were applied to the other groups (control group, $\mathrm{PCr}$ group) for 5 days after a single dose saline injection. At the end of the study, the biochemical parameters were examined in the blood and liver tissues taken from animals sacrificed by decapitation.

Results: MTX caused a significant increase in malondialdehyde and collagen levels and myeloperoxidase and caspase-3 activities, while glutathione levels were found to have decreased. $\mathrm{PCr}$ treatment showed protective efficacy by preventing these increases.

Conclusion: It appears that the administration of PCr to MTX treated rats prevented the accumulation of lipid peroxides, inflamatory reactions and depletion of antioxidant glutathione, and thus protected liver tissues against oxidative stress.

Keywords: Methotrexate, Petroselinum crispum, hepatotoxicity, oxidative injury, anti-inflammatory

\section{INTRODUCTION}

Methotrexate (MTX), a folic acid antagonist, has been used in the chemotherapy of malignant tumors for many years (1). It is also used in treatment of autoimmune diseases and for immunosuppressive therapy (2).

Once MTX enters the cell, it is polyglutamated and binds to dihydrofolate reductase (DHFR) with high af- finity, thus it inhibits the conversion of dihydrofolate to tetrahydrofolate. With this mechanism, the biosynthesis of thymidine and purines, which might be important for DNA synthesis, are blocked. Blocking tetrahydrofolate synthesis by methotrexate stops cell division and protein synthesis. It is known that the cytotoxic effect of MTX on the 'S phase' of the cell cycle is a factor that inhibits cell division (3). Moreover, this cytotoxic effect is not limited to only tumor cells; MTX is known to affect 
vital organs through endogenous oxidant systems and inflammatory pathways (4).

Unfortunately, most of the drugs approved for cancer treatment cause acute toxic effects in organs. The aforementioned toxic effects are more common in organs containing self-renewing cells such as bone marrow, the stomach and intestines, mucous membranes and hair follicles (5). In addition, it is known that oxidative products formed during the metabolism of agents used in cancer treatment are harmful to various organ systems such as the liver, heart, kidneys, lungs. Due to these adverse effects, dose restrictions are needed, but this limits the treatment (6). Similarly, in the liver, MTX is oxidized and converted to 7-hydoxymethotrexate, its major extracellular metabolite (7).

Oxidative stress develops due to the disturbed balance between oxidants and antioxidants, against or in favor of antioxidants. Free radicals are by-products formed during enzymatic events in cells and are cleared by antioxidant systems. However, when this formation exceeds the antioxidant capacity of the organism, oxidant substances damage the organs. Therefore, the use of antioxidants to prevent oxidant damage seems promising in treatment (8).

Petroselinum crispum (Parsley), a natural source of vitamins and minerals, is a green plant with important medicinal properties such as being antioxidant, anti-apoptotic, anti-inflammatory, anti-diabetic, as well as having nutritional properties (9). It contains antioxidant substances such as flavonoids (apigenin, luteolin), carotenoids and ascorbic acid (10). When the therapeutic potential of natural products is evaluated, there are many studies showing that they can be effective in different stress conditions such as oxidation, inflammation and liver disease. Multiple active ingredients extracted from different herbs and plants have potential in the treatment of hepatotoxicity with their potential antioxidant and anti-inflammatory properties (11). In our study, which we designed based on these data, we investigated whether aqueous PC extract was protective against MTX-induced liver damage with biochemical analyses.

\section{MATERIALS AND METHODS}

\section{Preparation of Plant Extracts}

Parsley (Petroselinum crispum, PC) leaves were collected from Istanbul, Turkey. Five grams of plant leaves were extracted with $50 \mathrm{~mL}$ distilled water for $30 \mathrm{~min}$ by boiling. Aqueous Parsley extract was then lyophilized and the obtained powdered extract was stored at $-20^{\circ} \mathrm{C}(12)$. The extract yield was $31.50 \% \mathrm{w} / \mathrm{w}$.

\section{Animals and Experimental Design}

Both sexes of Sprague Dawley rats (200-250 g) were divided into four groups containing 8 rats in each. The rats were housed in standard laboratory conditions: $22 \pm 2^{\circ} \mathrm{C}, 60-63 \%$ humidity and 12 hours light- 12 hours dark period, and were given water and feed ad libitum. All procedures for animals were approved by Marmara University Animal Experiments Local Ethics Commission (Protocol number: 26. 2019.mar). The study was carried out at the Marmara University Experimental Animals Application and Research Center (DEHAMER, Istanbul-Turkey).

Methotrexate was injected intraperitoneally $(20 \mathrm{mg} / \mathrm{kg})$ and $\mathrm{PCr}$ extract $(2 \mathrm{~g} / \mathrm{kg}$ ) was given orally. In the study, which consisted of four groups, the animals were divided into two groups (saline and PCr treatment groups) after a single dose of MTX administration, and a similarly saline and $\mathrm{PCr}$ treatment group after a single dose of saline administration. Saline (MTX group) or $\mathrm{PCr}$ (MTX+PCr group) was administered for 5 days. Alanine transaminase (ALT) and aspartate transaminase (AST), lactate dehydrogenase $(\mathrm{LDH})$ and proinflammatory cytokines were measured in the plasma while in the liver tissues malondialdehyde (MDA), glutathione (GSH), and collagen levels, and myeloperoxidase (MPO) and Caspase-3 activities were analyzed. Statistical analyses were completed with GraphPad Prism 8.0 (GraphPad Software, San Diego; CA; USA).

\section{Biochemical Analyses in Plasma and Liver Tissues}

Plasma AST, ALT and LDH levels were determined using the spectrophotometric method with an automatic analyzer. Plasma levels of tumor necrosis factor-a (TNF-a) and interleukin-1 $\beta$ (IL-1 $\beta$ ) were determined with purchased enzyme-linked immunosorbent assay (ELISA) kits specific for these proteins, according to the manufacturer's instructions (Biosource Int., Nivelles, Belgium).

To determine MDA and glutathione levels, the tissues were kept ready by homogenizing them in ice-cold $150 \mathrm{mM} \mathrm{KCl}$ (13). GSH determination was performed using a standard spectrophotometric method coupled with the use of Ellman reagent. The results were evaluated in $\mathrm{mmol} \mathrm{MDA} / \mathrm{g}$ tissue and $\mathrm{mmol} \mathrm{GSH} / \mathrm{g}$ tissue units (14).

The MPO activity in tissue was determined following the procedure according to Hillegas et al. (15). Tissues homogenized in potassium phosphate buffer (PB, 50mM pH 6.0) were centrifuged $(41,400 \mathrm{~g})$ for $10 \mathrm{~min}$ to obtain pellets. The pellets were suspended in $50 \mathrm{mM}$ PB with $0.5 \%$ hexadecyltrimethylammonium bromide (HETAB). $2.3 \mathrm{ml}$ volume of $50 \mathrm{mM}$ PB was added from aliquots to the mixture containing o-dianisidine and $20 \mathrm{mM} \mathrm{H}_{2} \mathrm{O}_{2}$ solution. The MPO activity was expressed as $\mathrm{U} / \mathrm{g}$ tissue.

The liver tissues were homogenized with $0.9 \% \mathrm{NaCl}$ and centrifuged at $1500 \mathrm{xg} 4^{\circ} \mathrm{C}$ for $10 \mathrm{~min}$. Caspase- 3 activities in the collected supenatants were measured using the commercial kit following the manufacturer's procedure (Abbkine Rat Caspase-3 ELISA Kit, Cat. number: KTE100992, China).

Determination of collagen is important as a free radical-derived fibrous marker. The tissues were fixed in 10\% formalin with paraffin in $0.1 \mathrm{M}$ phosphate buffer $(\mathrm{pH} ; 7.2)$, then $15 \mathrm{~mm}$ thick sections were obtained. This method is an assay based on the selective binding of Sirius Red and Fast Green FCF to collagen and non-collagen components, respectively, when sections are stained with both dyes dissolved in aqueous saturated picric 
acid. To determine the amount of collagen and protein, absorbances at 540 and $605 \mathrm{~nm}$ were read (16).

\section{Statistical Analysis}

Statistical analysis was performed using GraphPad Prism 8.0
(GraphPad Software, San Diego, CA, 230 USA). All data are expressed as the mean \pm standard error mean (SEM). The results of the all datas were analyzed using one-way ANOVA followed by Tukey's post hoc test. Statistical significance was accepted as $\mathrm{p}<0.05$.

Table 1. Plasma aspartate aminotransferase (AST), alanine aminotransferase (ALT), lactate dehydrogenase (LDH), TNF-a, and IL-1 $\beta$ Levels in the control (C), PCr, MTX and MTX+PCr groups.

\begin{tabular}{|c|c|c|c|c|}
\hline & C & $\mathrm{PCr}$ & MTX & $\mathrm{MTX}+\mathrm{PCr}$ \\
\hline AST (U/L) & $63.5 \pm 4.1$ & $53.5 \pm 4.5$ & $158.2 \pm 8.4^{* * *}$ & $94.2 \pm 12.6^{+++}$ \\
\hline $\mathrm{ALT}(\mathrm{U} / \mathrm{L})$ & $44.4 \pm 2.8$ & $43.0 \pm 3.5$ & $92.0 \pm 5.9 * * *$ & $53.0 \pm 7.5^{+++}$ \\
\hline LDH (U/L) & $362 \pm 22.3$ & $331 \pm 24.2$ & $715 \pm 97.6^{* *}$ & $386 \pm 68.3^{++}$ \\
\hline TNF-a (pg/mL) & $2.7 \pm 0.3$ & $2.6 \pm 0.5$ & $7.3 \pm 0.6^{* * *}$ & $3.7 \pm 0.5^{+++}$ \\
\hline IL-1ß (pg/mL) & $5.8 \pm 0.4$ & $5.7 \pm 0.8$ & $14.3 \pm 0.9 * * *$ & $9.5 \pm 0.9 *,++$ \\
\hline
\end{tabular}

a)

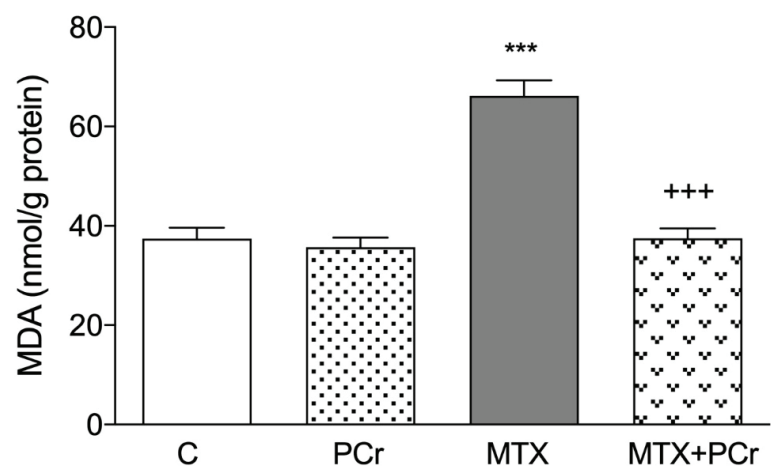

b)

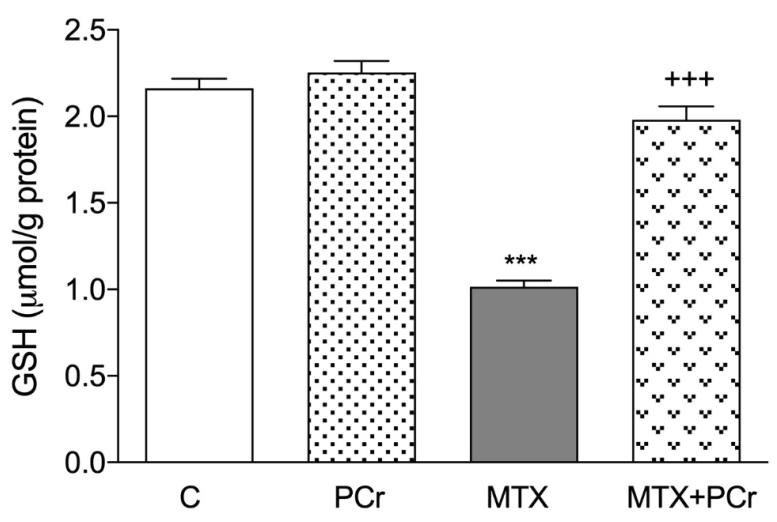

Figure 1. a) Malondialdehyde (MDA) and b) glutathione (GSH) levels the liver tissues of groups. ${ }^{* * *} \mathrm{p}<0.001$ : vs control group. ${ }^{+++} \mathrm{p}<0.001$ : vs saline-treated MTX group. C: Control, PCr: Petroselinum crispum, MTX: Metotreksat.

\section{RESULTS}

MTX-induced liver damage was evaluated by detecting ALT and AST levels, which are markers of liver function damage in the blood samples. When the results were examined, the level of these proteins increased with MTX application in the plasma samples. In addition to these, the level of tissue damage marker LDH and proinflammatory cytokines (TNF- $\alpha$, and IL-1 $\beta$ ) had also increased compared to the control group. $\mathrm{PCr}$ treatment significantly reduced these increased values compared to the MTX group $(p<0.01-0.001$, Table 1$)$.

While MTX application increased the MDA level in the tissue compared to the control, the GSH level decreased significantly. PCr treatment returned these results induced by MTX injection to control group levels ( $p<0.001$; Figure 1$)$.

The level of MPO, which is evidence of neutrophil infiltration, increased significantly $(p<0.001)$ after MTX injection compared to the control group. The level of MPO, which is evidence of neutrophil infiltration, was significantly increased after MTX injection compared to the control group. On the other hand, the liver MPO level had significantly decreased in the MTX+PCr group compared to the MTX group. This was a consistent result in accordance with the antioxidant and anti-inflammatory properties of $\mathrm{PCr}(\mathrm{p}<0.001$, Figure $2 \mathrm{a})$.

Similarly, the caspase-3 activity, as an apoptotic marker, was found to have significantly increased $(p<0.001)$ due to MTX administration. However, treatment with $\mathrm{PCr}$ of the rats given MTX, significantly prevented $(p<0.01)$ the increase in caspase- 3 activity, and the levels were close to the control group (Figure 2b).

Methotrexate administration caused a significant increase $(p<0.001)$ in hepatic tissue collagen levels. However, when $\mathrm{PCr}$ was given following MTX, the collagen levels reduced significantly ( $p<0.05$, Figure 3$)$. 
a)

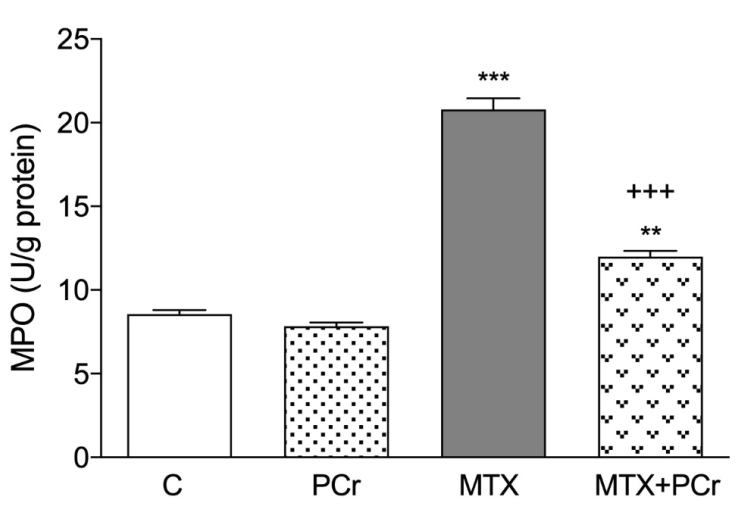

b)

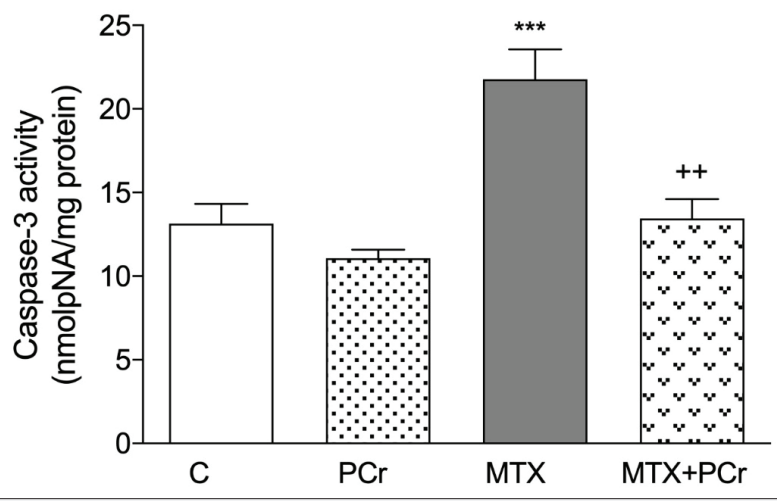

Figure 2. a) Myeloperoxidase (MPO) and b) caspase-3 activities in the liver tissues of groups. ${ }^{* *} p<0.001,{ }^{* *} p<0.01$ : vs control group. $+++p<0.001,++p<0.01$ : vs saline-treated MTX group. C: Control, PCr: Petroselinum crispum, MTX: Metotreksat.

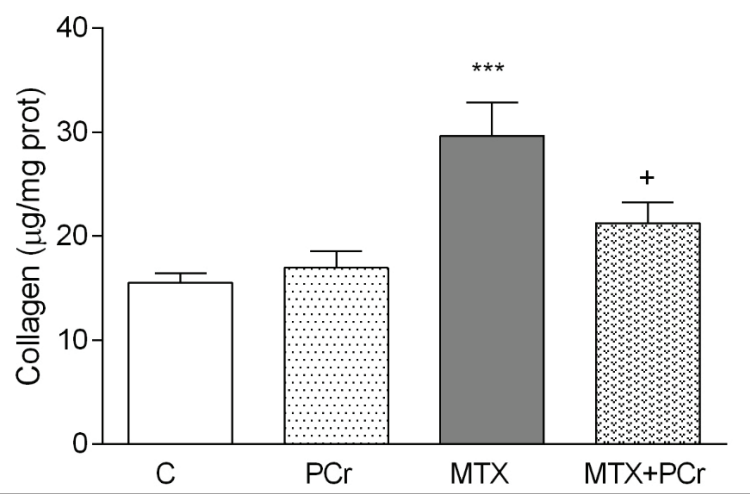

Figure 3. Collagen levels in the liver tissues of groups. ${ }^{* * *} \mathrm{p}<0.001$ : vs control group. ${ }^{+} \mathrm{p}<0.05$; vs saline-treated MTX group. C: Control, PCr: Petroselinum crispum, MTX: Metotreksat.

\section{DISCUSSION}

With its folate antagonist effect, MTX is a drug that is preferably used clinically in the treatment of leukemia and various other solid tumors (17). Based on our results, the increase in MDA level with MTX application and the increase in caspase-3 activity, which is a marker defining the apoptotic process, indicate a hepatotoxic state accompanied by oxidative damage. It was observed that the level of GSH, an important antioxidant, decreased in parallel with the increased oxidative stress. In addition, the MTX caused a significant inflammation process with an increase in proinflammatory cytokines accompanied by an increase in MPO in the tissue. The known antioxidant and anti-inflammatory activity of parsley has been a therapeutic factor in the treatment of many diseases. We designed our study based on the potential effectiveness of hepatotoxicity through the same properties. In addition, this oxidant and inflammation increase decreased with $\mathrm{PCr}$ treatment in the hepatotoxicity group treated with MTX.

The factors responsible for MTX toxicity are the age of the patient, other diseases present in the patient, predisposing factors to toxicity, as well as MTX metabolites. 7-hydoxymethotrexate is the major oxidant metabolite of MTX, which is formed as a result of oxidase-mediated (aldehyde oxidase) biotransformation reactions in the liver (18). In the long-term administration of MTX, another mechanism responsible for hepatic toxicity is its other metabolites which are accumulated as polyglutamates (19). MTX inhibits nicotinamide adenosine diphosphate $[N A D(P)]$-dependent dehydrogenases and the NADP malic enzyme, which control the production of NADPH (20). By providing a reduced glutathione level, NADPH has played a mediating role in a kind of antioxidant defense mechanism of the cell (21). This mechanism induced by MTX causes a decreased GSH level, leaving cells vulnerable to oxidant stress (22). Since this situation mediates hepatic toxicity and the pathogenesis of organ failure in clinical situations that require treatment with MTX, it is an essential to prevent this effect. Recent studies in the literature have shown that plants and major compounds obtained from plants are protective against this effect, which limits the use of MTX, thanks to their antioxidant effects. It was concluded that treatment with Ginkgo biloba extract treats MTX-induced hepatic injury by reducing the level of proinflammatory cytokines (23). A study by Famurewa et al. (24) examined the effect of Hibiscus sabdariffa extract on hepatic damage caused by MTX injection. The results obtained were interpreted as oxidant damage in the tissue was treated with the antioxidant properties of Hibiscus sabdariffa extract (24).

Petroselinum crispum (parsley), besides its use as a spice, is one of the most beneficial herbs for health due to its vitamins and mineral contents. In addition to its antidiabetic, antihypertensive, cholesterol-lowering, diuretic effects, various mixtures are prepared and used in knee and lower back pain (12). Parsley (Petroselinum crispum), which belongs to the Umbellifera plant family, is a widely grown annual herb. Today, herbs are being researched with increasing interest and speed, and those that 
have been shown to have benefits are considered as alternative agents as new, safe and effective therapeutics (25). Petroselinum crispum, a culinary herb originating from the Mediterranean region, has become a common herb worldwide in modern times and has been studied in many experimental models examining its antioxidant properties (26). Yanardag et al. demonstrated the hypoglycemic effects of $\mathrm{PCr}$ extract in streptozotocin-induced diabetic rats (12). Furthermore, Sener et al. showed that $\mathrm{PCr}$ extract, besides reducing glucose level, also prevented diabetes-induced oxidant damage in the heart and tissue of diabetic rats through its antioxidant properties (27). Indeed, decreased GSH levels with increasing damage in heart and aorta tissues show that this diabetic damage is related to oxygen radicals. On the other hand, GSH levels were preserved in diabetic animals treated with PCr through with its antioxidant properties (28). Similarly, in this study, it is thought that MTX has a protective effect against liver tissue damage with its antioxidant effect. Similarly, in our study, it is thought that the decreased GSH levels in liver tissue damage caused by MTX are restored with the antioxidant effect of PCr and the tissue is protected.

Free radicals trigger inflammatory reactions, further increasing tissue damage. Thus, it causes an increase in pro-inflammatory cytokines and migration of neutrophils to the tissues (29). Neutrophils have an important role in host defense and innate immune response against harmfull agents (30). However, along with these beneficial effects, in cases of hyperactivity, neutrophils when infiltrating to the tissue, release MPO enzyme, which has an oxygen radical-dependent microbicidal activity, also causes inflammation or tissue damage (31). In accordance with the previous findings, MTX administration caused an increase in the proinflammatory cytokines, TNF- $\alpha$ and IL-1 $\beta$ in blood, and the activity of MPO enzyme in liver tissue (32). PCr extract given to MTX group prevented oxidant damage, and prevented inflammatory reactions Alleviation of tissue damage by PCr extract treatment and decreased AST, ALT and LDH levels increased by MTX suggest that liver functions are also preserved.

As is well known, ROS-mediated DNA damage results in apoptosis (33). In fact, apoptosis, defined as programmed cell death, is induced by MTX activating the mitochondrial extrinsic apoptotic pathway (34). Studies have shown that MTX-mediated apoptosis occurs by the amplified expression of proapoptotic genes such as TNF-a, caspase-3 and COX-2 (35). As a result we found that PCr extract has an anti-inflammatory activity and that MTX-induced caspase- 3 and TNF-alpha increase could be prevented by treatment. One of the liver fibrosis parameters is the amount of tissue collagen present (36). It has already been proven by various researchers that MTX tends to increase the level of tissue collagen (37). In our own results, the increase of tissue collagen level by MTX induction is supported by the results obtained. However, treatment with $\mathrm{PCr}$ was effective in preventing hepatotoxicity in MTX-induced fibrosis by significantly reducing the level of collagen, which explains the additional antifibrotic mechanism involved in hepatoprotection of PCr.

\section{CONCLUSION}

In conclusion, it can be said that PCr treatment has a protective effect against MTX-induced hepatotoxicity by eliminating lipid peroxide accumulation and restoring GSH levels through its antioxidant property. $\mathrm{PCr}$ treatment also inhibited inflammatory reactions. According to these results, $\mathrm{PCr}$ treatment is thought to be a potential protective factor against organ damage which is encountered in chemotherapy with MTX. Broader research with the major compounds of the plant mediating this activity should be considered.

Ethics Committee Approval: This study was approved by Marmara University Animal Experiments Local Ethics Commission (Protocol number: 26. 2019.mar).

Informed Consent: Written consent was obtained from the participants.

Peer Review: Externally peer-reviewed.

Author Contributions: Conception/Design of Study- B.E., F.B.T., G.S.; Data Acquisition- B.E., F.B.T., G.S.; Data Analysis/Interpretation- B.E., F.B.T., B.E., O.S., G.S.; Drafting Manuscript- B.E., D.O., G.S.; Critical Revision of Manuscript- D.O., R.Y., G.S.; Final Approval and Accountability- B.E., F.B.T., D.O., R.Y., O.S., G.S.

Conflict of Interest: Authors declared no conflict of interest.

Financial Disclosure: Authors declared no financial support.

\section{REFERENCES}

1. Wang W, Zhou H, Liu L. Side effects of methotrexate therapy for rheumatoid arthritis: A systematic review. Eur J Med Chem 2018; 158: 502-16.

2. Rizzi R, Curci P, Delia M, Rinaldi E, Chiefa A, Specchia G, et al. Spontaneous remission of "methotrexate-associated lymphoproliferative disorders" after discontinuation of immunosuppressive treatment for autoimmune disease. Review of the literature. Med Oncol 2009; 26 (1): 1-9.

3. Sayılmaz A, Karabulut YY, Özgörgülü A. The histopathological evaluation of healing effects of vitamin $\mathrm{C}$ administered before methotrexate therapy on testicular injury induced by methotrexate. Turk J Urol 2016; 42(4): 235-9.

4. El-Sheikh AA, Morsy MA, Al-Taher AY. Multi-drug resistance protein (Mrp) 3 may be involved in resveratrol protection against methotrexate-induced testicular damage. Life Sci 2014; 119(1-2): 40-6.

5. Taguchi T. [Side effects of cancer chemotherapy and steps to deal with them]. Gan To Kagaku Ryoho. 1995; 22(14): 2017-28.

6. Goto E, Hosomi M, Nishihara M, Goto M, Yoshida M, Kii T, et al. [Comparison of chemotherapy side effects between elderly and young subjects]. Gan To Kagaku Ryoho 2012; 39(13): 2527-31.

7. Jahovic N, Cevik H, Sehirli AO, Yeğen BC, Sener G. Melatonin prevents methotrexate-induced hepatorenal oxidative injury in rats. J Pineal Res 2003; 34(4): 282-7.

8. Athreya K, Xavier MF. Antioxidants in the Treatment of Cancer. Nutr Cancer 2017; 69(8): 1099-104.

9. Ozsoy-Sacan O, Yanardag R, Orak H, Ozgey Y, Yarat A, Tunali T. Effects of parsley (Petroselinum crispum) extract versus glibornuride on the liver of streptozotocin-induced diabetic rats. J Ethnopharmacol 2006; 104(1-2): 175-81. 
10. Tunali T, Yarat A, Yanardağ R, Ozçelik F, Ozsoy O, Ergenekon G, et al. Effect of parsley (Petroselinum crispum) on the skin of STZ induced diabetic rats. Phytother Res 1999; 13(2): 138-41.

11. Malayeri A, Badparva R, Mombeini MA, Khorsandi L, Goudarzi M. Naringenin: a potential natural remedy against methotrexate-induced hepatotoxicity in rats. Drug Chem Toxicol 2020: 1-8.

12. Yanardağ R, Bolkent S, Tabakoğlu-Oğuz A, Ozsoy-Saçan O. Effects of Petroselinum crispum extract on pancreatic $B$ cells and blood glucose of streptozotocin-induced diabetic rats. Biol Pharm Bull 2003; 26(8): 1206-10.

13. Sener G, Paskaloglu K, Toklu H, Kapucu C, Ayanoglu-Dulger G, Kacmaz A, et al. Melatonin ameliorates chronic renal failure-induced oxidative organ damage in rats. J Pineal Res 2004; 36(4): 232-41.

14. Sener G, Sehirli AO, Ayanoglu-Dülger G. Melatonin protects against mercury(II)-induced oxidative tissue damage in rats. Pharmacol Toxicol 2003; 93(6): 290-6.

15. Hillegass LM, Griswold DE, Brickson B, Albrightson-Winslow C. Assessment of myeloperoxidase activity in whole rat kidney. J Pharmacol Methods 1990; 24(4): 285-95.

16. López-De León A, Rojkind M. A simple micromethod for collagen and total protein determination in formalin-fixed paraffin-embedded sections. J Histochem Cytochem 1985; 33(8): 737-43.

17. Burmester GR, Pope JE. Novel treatment strategies in rheumatoid arthritis. Lancet 2017; 389(10086): 2338-48.

18. Seideman $P$, Beck O, Eksborg S, Wennberg M. The pharmacokinetics of methotrexate and its 7-hydroxy metabolite in patients with rheumatoid arthritis. Br J Clin Pharmacol 1993; 35(4): 409-12.

19. Conway R, Carey JJ. Risk of liver disease in methotrexate treated patients. World J Hepatol 2017; 9(26): 1092-100.

20. Kim J, Kim KY, Jang HS, Yoshida T, Tsuchiya K, Nitta K, et al. Role of cytosolic NADP+-dependent isocitrate dehydrogenase in ischemia-reperfusion injury in mouse kidney. Am J Physiol Renal Physiol 2009; 296(3): F622-33.

21. Espinosa-Diez C, Miguel V, Mennerich D, Kietzmann T, Sánchez-Pérez P, Cadenas $\mathrm{S}$, et al. Antioxidant responses and cellular adjustments to oxidative stress. Redox Biol 2015; 6: 183-97.

22. Eki Nci-Akdemi R FN, Yildirim S, Kandemi R FM, Gülçi N I, Küçükler $S$, Sağlam YS, et al. The effects of casticin and myricetin on liver damage induced by methotrexate in rats. Iran J Basic Med Sci 2018; 21(12): 1281-8.

23. Sherif IO, Al-Shaalan NH. Hepatoprotective effect of Ginkgo biloba extract against methotrexate-induced hepatotoxicity via targeting STAT3/miRNA-21 axis. Drug Chem Toxicol 2020: 1-9.

24. Famurewa AC, Folawiyo AM, Epete MA, Igwe EC, Okike PI, Maduagwuna EK. Abrogation of Hepatic Damage Induced by Anticancer Drug Methotrexate by Zobo (Hibiscus sabdariffa extract) Supplementation via Targeting Oxidative Hepatotoxicity in Rats. J Diet Suppl 2019; 16(3): 318-30.
25. Liberal Â, Fernandes Â, Polyzos N, Petropoulos SA, Dias MI, Pinela $J$, et al. Bioactive Properties and Phenolic Compound Profiles of Turnip-Rooted, Plain-Leafed and Curly-Leafed Parsley Cultivars. Molecules 2020; 25(23): 5606.

26. Bolkent S, Yanardag R, Ozsoy-Sacan O, Karabulut-Bulan O. Effects of parsley (Petroselinum crispum) on the liver of diabetic rats: a morphological and biochemical study. Phytother Res 2004; 18(12): 996-9.

27. Ozel AB, Cilingir-Kaya OT, Sener G, Ozbeyli D, Sen A, Sacan O, et al. Investigation of possible neuroprotective effects of some plant extracts on brain in bile duct ligated rats. J Food Biochem 2021: e13835.

28. Sener G, Kapucu C, Paskaloglu K, Ayanoglu-Dülger G, Arbak S, Ersoy $Y$, et al. Melatonin reverses urinary system and aorta damage in the rat due to chronic nicotine administration. J Pharm Pharmacol 2004; 56(3): 359-66.

29. Sener G, Ekşioğlu-Demiralp E, Cetiner M, Ercan F, Yeğen BC. Beta-glucan ameliorates methotrexate-induced oxidative organ injury via its antioxidant and immunomodulatory effects. Eur J Pharmacol 2006; 542(1-3): 170-8.

30. Nauseef WM, Metcalf JA, Root RK. Role of myeloperoxidase in the respiratory burst of human neutrophils. Blood 1983; 61(3): 483-92.

31. Mortaz E, Alipoor SD, Adcock IM, Mumby S, Koenderman L. Update on Neutrophil Function in Severe Inflammation. Front Immunol 2018; 9: 2171.

32. Abdellatief SA, Galal AA, Farouk SM, Abdel-Daim MM. Ameliorative effect of parsley oil on cisplatin-induced hepato-cardiotoxicity: A biochemical, histopathological, and immunohistochemical study. Biomed Pharmacother 2017; 86: 482-91.

33. Al Kury LT, Dayyan F, Ali Shah F, Malik Z, Khalil AAK, Alattar A, et al. Ginkgo biloba Extract Protects against Methotrexate-Induced Hepatotoxicity: A Computational and Pharmacological Approach. Molecules 2020; 25 (11).

34. Ali N, Rashid S, Nafees S, Hasan SK, Sultana S. Beneficial effects of Chrysin against Methotrexate-induced hepatotoxicity via attenuation of oxidative stress and apoptosis. Mol Cell Biochem 2014; 385(1-2): 215-23.

35. Kelleni MT, Ibrahim SA, Abdelrahman AM. Effect of captopril and telmisartan on methotrexate-induced hepatotoxicity in rats: impact of oxidative stress, inflammation and apoptosis. Toxicol Mech Methods 2016; 26(5): 371-7.

36. De S, Kundu S, Chatterjee U, Chattopadhyay S, Chatterjee M. Allylpyrocatechol attenuates methotrexate-induced hepatotoxicity in a collagen-induced model of arthritis. Free Radic Res 2018; 52(6): 698-711.

37. Tawfik MK. Combination of coenzyme Q10 with methotrexate suppresses Freund's complete adjuvant-induced synovial inflammation with reduced hepatotoxicity in rats: Effect on oxidative stress and inflammation. Int Immunopharmacol 2015; 24(1): 80-7. 